\title{
Characterization of mucosal immunity in rainbow trout Oncorhynchus mykiss challenged with infectious hematopoietic necrosis virus: identification of antiviral activity
}

\author{
Kenneth D. Cain ${ }^{1, *}$, Scott E. LaPatra ${ }^{2}$, Thomas J. Baldwin ${ }^{3}$, Bill Shewmaker ${ }^{2}$, \\ Jerry Jones ${ }^{2}$, Sandra S. Ristow ${ }^{1}$ \\ ${ }^{1}$ Dept of Animal Sciences, Washington State University, Pullman, Washington 99164-6332, USA \\ ${ }^{2}$ Clear Springs Foods, Inc., PO Box 712, Buhl, Idaho 83316, USA \\ ${ }^{3}$ Dept of Veterinary Microbiology and Pathology, Washington Animal Disease Diagnostic Laboratory, Washington State \\ University, Pullman, Washington 99164-6332, USA
}

\begin{abstract}
Cutaneous and lower gastrointestinal (GI) tract mucus of rainbow trout Oncorhynchus mykiss were evaluated for immunological responses following exposure to infectious hematopoietic necrosis virus (IHNV). Juvenile rainbow trout (mean weight $5.4 \mathrm{~g}$ ) were infected with IHNV (isolate 220-90) by waterborne exposure to $10^{4}$ plaque forming units (pfu) $\mathrm{ml}^{-1}$ or by an injection challenge of $10^{4} \mathrm{pfu}_{\text {fish }}^{-1}$. Cutaneous mucus and lower GI tract washings were analyzed for virus neutralizing activity (antiviral activity) using a complement-dependent neutralization procedure. Antiviral activity was primarily detected in the GI tract and was highest in mock infected fish (not exposed to virus). This activity decreased rapidly over time in fish challenged by the injection route. Specific antibodies were not detected in cutaneous mucus or Gl tract washings by ELISA. Virus was isolated in external and Gl tract mucus from both waterborne and injection challenged fish, and showed significantly higher titers in fish challenged by the injection route. Histological examination of fish exposed to IHNV showed a moderate inflammatory response in the mucosal epithelial layer of the skin with minor focal areas of cellular necrosis in severely infected fish. When the study was repeated, in addition to cutaneous mucus and GI tract washings, serum was monitored for antibody production in juvenile rainbow trout (mean weight $2.4 \mathrm{~g}$ ) out to 28 days post-exposure (dpe). Antiviral activity was confirmed in the GI mucus, and virus neutralizing antibodies were detected in the serum at 21 and 28 dpe in IHNV challenged fish Antibodies in skin and GI mucus were not detected by ELISA. Virus antigen was visualized by immunohistochemistry in the kidney, spleen, liver, heart, pancreatic tissue, and smooth muscle of the stomach wall. Results from these experiments reveal innate mechanisms of viral resistance which may be important as a first line of defense against IHNV.
\end{abstract}

KEY WORDS: IHNV $\cdot$ Mucosal immunity $\cdot$ Antiviral activity $\cdot$ Rainbow trout

\section{INTRODUCTION}

Characterization of specific immune components in cutaneous and intestinal mucus is incomplete in fish. but the importance of the mucosal barrier in preventing invasion by pathogens is clear. Besides acting as a

\footnotetext{
•E-mail: ristow@wsu.edu
}

physical barrier, mucus covering mucosal surfaces contains antibodies and other immune components (Hart et al. 1988, Davidson 1991). The purpose of this study is to clarify mucosal immunity in rainbow trout Oncorhynchus mykiss challenged with infectious hematopoietic necrosis virus (IHNV).

IHNV is enzootic to the Pacific Northwest (United States) and causes the disease infectious hematopoietic necrosis (IHN), which affects juvenile sockeye 
salmon Oncorhynchus nerka, chinook salmon O. tshawytscha and rainbow trout, causing large losses of hatchery and possibly wild stocks (Wolf 1988). Control of IHN is achieved only through avoidance (utilizing pathogen free stocks and water sources); no vaccines or effective chemotherapeutants are available. No successful means of control during an epizootic exist, although under certain circumstances manipulation of water temperatures may be useful. (Amend 1970). The use of antiviral compounds for control of IHNV has been explored (Hasobe \& Saneyoshi 1985), and although these compounds were effective in tissue culture, they were ineffective in vivo. Experimental vaccines that provide varied levels of protection have been developed, but adaptation of vaccines for use in commercial facilities has not been accomplished (Gilmore et al. 1988, Leong et al. 1988).

In mammals, the mucosal immune system accounts for approximately $70 \%$ of total antibody (Service 1994). Antibodies localized to the mucosae are of the IgA isotype and provide a first line of defense against pathogens invading mucosal sites. Increased understanding of the mucosal immune system has made possible the development of vaccines which elicit a specific mucosal immune response (McGhee et al. 1992). In fish, knowledge of the mucosal immune system is limited (St. Louis-Cormier et al. 1984, Hart et al. 1988, Davidson 1991, Loghothetis \& Austin 1994) and the role it plays with respect to IHNV is unknown. IHNV has been isolated from mucosal surfaces (LaPatra et al. 1989, Yamamoto et al. 1992, Helmick 1995a, b) and since fish are bathed in mucus (internally and externally) the virus must cross a mucosal barrier to cause disease. It is hypothesized that mucosal immunity plays a critical role as a first line of defense against invasion by IHNV.

Over the past 2 decades the presence of a primitive mucosal immune system in fish has been investigated, and researchers have demonstrated the presence of antibodies and other non-specific immune components in fish mucus (Ingram 1980, Lobb 1987, Austin \& McIntosh 1988, Rombout \& van den Berg 1989, Rombout et al. 1989a, b, Jenkins et al. 1994). St. Louis-Cormier et al. (1984) found that intraperitoneal (i.p.) injection of sheep red blood cells induced antigenically similar antibodies in both serum and mucus of trout. Antibody titers in mucus were lower than those in serum; mucus smears contained lymphoblasts, small lymphocytes and mature plasma cells in addition to epithelial cells. Lobb (1987) immunized catfish by immersion in water containing dinitrophenylated (DNP) horse serum albumin, and anti-DNP antibody was identified in cutaneous mucus. Mucosal antibodies had the same tetrameric form as serum anti-DNP antibodies and the same molecular weight heavy and light chains. Lobb also found numerous lymphocytes within the epidermis associated primarily with the basal layer. Loghothetis \& Austin (1994) identified antibodies in the serum, bile, skin and gut mucus from fish immunized with killed and live cells of Aeromonas hydrophila by injection, immersion and oral routes. The antibody titer in gut mucus increased for 10 to $12 \mathrm{wk}$ after administration of antigen of $A$. hydrophila, particularly when the bacteria were given orally. Interestingly, there was no correlation between serum and gut mucus antibody titers. Skin mucus also contained immunoglobulin (Ig), which increased in titer for up to $12 \mathrm{wk}$ after antigen exposure then declined and rose again after secondary antigen administration. Serum antibody responses did not parallel mucosal antibody responses, suggesting a local immune response. Nevertheless, it is currently unknown if antibodies found in the mucus of fish are derived locally, as occurs in mammals, or if they are produced systemically and transported across epithelial layers into secretions.

Although the fish intestine lacks immunological structures such as Peyer's patches, it is believed that the fish intestine is immunocompetent (Hart et al. 1988). The anterior intestine in teleosts is the site primarily involved in lipid and protein absorption, while the posterior intestine is involved with the absorption of macromolecular proteins (Vernier 1990). The common carp Cyprinus carpio has received the most study related to the intestinal immune system. In carp, the uptake and processing of antigens such as soluble ferritin and particulate bacteria Vibrio anguillarum have been studied (Rombout \& van den Berg 1989, Rombout et al. 1989a, b). Both antigens are taken up in the second segment of the gut by intestinal epithelial cells. Antigen is localized in supranuclear vacuoles in epithelial cells and in large intraepithelial macrophages. Binding of both antigens by mucosal associated macrophages was observed (Rombout \& van den Berg 1989). Rombout et al. (1989a) found few lymphocytes in this region that were Ig positive (B cells) and suggested that unlabeled lymphocytes may be T-like cells, which may be indicative of cell-mediated defense mechanisms.

To summarize, evidence thus far suggests that fish have the ability to mount an immune response at mucosal sites and that skin and gut mucus may provide an important first line of defense. This study examined the mucosal irmmune response of rainbow trout exposed to IHNV to clarify the role of mucosal immunity in IHN. The objectives of this study were to characterize the mucosal immune response in rainbow trout challenged with IHNV, and to examine mucosal surfaces for pathologic changes and virus amplification. 


\section{MATERIALS AND METHODS}

Fish challenges. Two separate trials were conducted to examine the local (mucosal) immune response in rainbow trout challenged with IHNV. Fish stocks for each experiment were obtained from Clear Springs Foods Inc., Buhl, Idaho, USA, and all challenges were conducted at their research facility. Prior to challenges, fish were held in $116 \mathrm{l}$ tanks at $15^{\circ} \mathrm{C}$ in a single pass flow-through system. In the first experiment (Expt 1), rainbow trout (mean weight $5.4 \mathrm{~g}$ ) were challenged with IHNV (isolate 220-90; LaPatra et al. 1991) by intraperitoneal (i.p.) injection or waterborne exposure, or were mock challenged with phosphate-buffered saline (PBS). Injected fish were anesthetized with MS-222 (Argent chemical, Redmond, WA, USA) and each inoculated with $50 \mu \mathrm{l}$ of PBS containing $10^{4}$ plaque forming units (pfu) of IHNV. Waterborne infection was accomplished by immersing fish for $1 \mathrm{~h}$ in $1.6 \mathrm{l}$ of aerated spring water containing $10^{4}$ pfu $\mathrm{ml}^{-1}$ of IHNV. Mock challenged (control) fish were treated identically to the waterborne exposure groups, but received only PBS.

In the second experiment (Expt 2), rainbow trout (mean weight $2.4 \mathrm{~g}$ ) were challenged with IHNV by waterborne exposure $\left(10^{4} \mathrm{pfu} \mathrm{ml}^{-1}\right)$ or mock exposed to PBS (no fish were injected).

Experimental design. The design for each experiment is outlined and described in Table 1. Following virus challenge in Expt 1, 11 test groups (30 fish per tank) were placed in 201 containers supplied with ultra-violet light treated specific-pathogen-free (SPF) spring water at $15^{\circ} \mathrm{C}$ in a continuous flow-through system. Replicate tanks of both waterborne and injection challenged groups and a single tank containing mock challenged fish were monitored for mortality. Three sub-sample tanks, one tank for each treatment group, were treated identically and maintained for removal of fish for histology and analysis of external and GI mucus for neutralizing activity and antibody production. Three additional sub-sample tanks were maintained for isolation of virus from external and GI tract mucus. All fish were removed from feed $48 \mathrm{~h}$ prior to challenges and remained off feed throughout the $10 \mathrm{~d}$ experiment.

Table 1. Experimental design

\begin{tabular}{|lcc|}
\hline & Expt 1 & Expt 2 \\
\hline Fish size (g) & 5.4 & 2.4 \\
Fish per tank & 30 & 40 \\
Tanks & 11 & 7 \\
Sub-sample tanks & 6 & 4 \\
Length of study (d) & 10 & 28 \\
\hline
\end{tabular}

In Expt 2, 7 test groups ( 40 fish per tank) were placed in 20 l containers supplied with ultra-violet light treated specific-pathogen-free (SPF) spring water at $15^{\circ} \mathrm{C}$ in a continuous flow-through system following virus challenge. Replicate tanks of IHNV infected fish and a single tank containing mock infected fish were monitored for mortality. Two sub-sample tanks, one tank for each treatment group, were maintained for removal of fish for histology and analysis of external and GI mucus for neutralizing activity and antibody production. Two additional sub-sample tanks were maintained for isolation of virus in external and Gl tract mucus. Fish were taken off feed $24 \mathrm{~h}$ prior to challenges. During the experiment, fish were fed twice daily, but removed from feed $72 \mathrm{~h}$ before sampling to ensure that no food was present in the GI tract.

Sampling. In Expt 1, 5 randomly selected fish were removed from mock challenged groups and sacrificed on Days 0, 1, 3 and 8, while IHNV challenged groups were sampled in the same manner on Days $1,2,3,6,8$ and 10. Cutaneous and lower GI tract mucus was collected from each fish. Cutaneous mucus was collected by placing individual fish in $2.0 \mathrm{mil}$ (=0.05 $\mathrm{mm}$ thick) clear polypropylene bags for approximately 4 to $5 \mathrm{~min}$. Fish were removed, and mucus within each bag was collected in $0.5 \mathrm{ml}$ microfuge tubes. Gastrointestinal mucus was collected by removing the lower GI tract from sacrificed fish and first expelling any remaining fecal material by light external digital pressure with blunt forceps. Intestinal mucus was then collected by inserting a $1 \mathrm{cc}$ syringe, containing $200 \mu \mathrm{l}$ PBS and fitted with a 20 gauge needle, into the anterior end of the excised intestinal tract and flushing material into a $0.5 \mathrm{ml}$ microfuge tube. Any remaining mucus was expelled with forceps. Samples obtained from GI tract washings were vortexed to allow thorough mixing, and then centrifuged at $1600 \times \mathrm{g}$. Cutaneous and GI tract mucus was assayed for anti-IHNV neutralizing activity using a complement-dependent $50 \%$ plaque neutralization procedure (LaPatra et al. 1993, Ristow et al. 1993) and for specific antibodies using a modified ELISA (Arkoosh \& Kaattari 1990, Ristow et al. 1993; see below). Virus isolation was attempted from all mucus samples and from kidney-liver-spleen homogenates from a minimum of $20 \%$ daily mortalities using a plaque assay (LaPatra et al. 1989). Additionally, sections of dorsal skin and epaxial muscle were removed for histology and fixed in $10 \%$ neutral buffered formalin (NBF). These sections were obtained by removing approximately a $2 \mathrm{~cm}^{2}$ piece of skin with underlying muscle from behind the operculum extending horizontally along the lateral line and vertically to the base of the dorsal fin. Fixed tissues were paraffin embedded using standard procedures and sectioned at $5 \mu \mathrm{m}$. 
In Expt 2, groups of fish were monitored at 1, 7, 14, 21 and $28 \mathrm{~d}$ post-exposure (dpe) for antiviral activity in the serum, cutaneous mucus and GI tract mucus. Random samples of 5 fish were removed from tanks at weekly intervals. In an effort to increase yields of cutaneous mucus, $200 \mu \mathrm{l}$ of $0.85 \%$ (physiological) saline was added to each polypropylene bag prior to addition of fish the use of PBS or $0.85 \%$ physiological saline was necessary to obtain a large enough sample size for analysis and resulted in an initial dilution of those samples). Serum samples were obtained by severing the caudal peduncle and collecting blood in $0.1 \mathrm{ml}$ hematocrit tubes. Blood from each fish in the pool was combined and allowed to clot at $4^{\circ} \mathrm{C}$ overnight. Serum was harvested after samples were centrifuged at $1600 \times g$ for $5 \mathrm{~min}$. Whole fish were opened ventrally and immersed in $10 \% \mathrm{NBF}$. Cutaneous and GI mucus were examined for the presence of virus, specific antibody and IHNV neutralizing activity (see methods below). Virus isolation and neutralizing activity assays were conducted within $24 \mathrm{~h}$ of sample collection in both experiments, while samples to be assayed by ELISA were stored at $-70^{\circ} \mathrm{C}$ until analyses could be performed.

Enzyme linked immunoassay (ELISA). An ELISA to detect the presence of antibody against IHNV in the mucus of rainbow trout was developed. The ELISA was modeled after other methods described for antibody detection (Arkoosh \& Kaattari 1990, Ristow et al. 1993). Briefly, 96-well Immulon I microtiter plates were coated with $0.05 \mu \mathrm{g}$ of purified IHNV per well (isolate $220-90)$ in bicarbonate coating buffer $\left(0.795 \mathrm{~g} \mathrm{NaCO}_{3}\right.$ and $1.465 \mathrm{~g} \mathrm{NaHCO}_{3}$ in $500 \mathrm{ml}$ double distilled water adjusted to $\mathrm{pH} 9.6$ ) overnight at $4^{\circ} \mathrm{C}$. Wells were blocked with $3 \%$ bovine serum albumin (BSA) in phosphate-buffered saline containing $0.05 \%$ Tween 20 (PBST-BSA $3 \%$ ) for $2 \mathrm{~h}$ at room temperature. Replicate samples of mucus were diluted $(1: 4,1: 8,1: 16$ and 1:32) in PBST-BSA $3 \%$ and incubated for $24 \mathrm{~h}$ at $16^{\circ} \mathrm{C}$. A biotinylated mouse anti-trout immunoglobulin (DeLuca et al. 1983) was applied and incubated for $1 \mathrm{~h}$ at $37^{\circ} \mathrm{C}$. A 1:3000 dilution of streptavidin-peroxidase (Zymed, San Francisco, CA, USA) in PBST-BSA $1 \%$ was applied for $1 \mathrm{~h}$ at $37^{\circ} \mathrm{C}$. Finally, $0.1 \%$ 5-amino salicylic acid containing $0.005 \%$ hydrogen peroxide was added and allowed to react in the dark for $1 \mathrm{~h}$. Plates were read at 490 nm using a Cambridge plate reader spectrophotometer. Anti-IHNV titers were considered positive if the reciprocal of the highest dilution was twice the background control (negative serum) optical density value (Voller et al. 1979). Wells were rinsed between steps with PBST.

Complement-dependent neutralization. Virus neutralizing activity in skin and GI mucus and serum of rainbow trout was analyzed using a complement- dependent, 50\% plaque neutralization assay (LaPatra et al. 1993, Ristow et al. 1993). Samples were heatinactivated $\left(45^{\circ} \mathrm{C}\right.$ for $\left.30 \mathrm{~min}\right)$ to destroy residual complement, and 2 -fold dilutions of mucus (1:4 to $1: 32)$ and serum (1:20 to $1: 160)$ were made in $50 \mu \mathrm{l}$ Hanks' balanced salt solution in 96 -well round bottom tissue culture plates (Corning Glassworks, Corning, NY, USA). An equal volume of diluted virus (IHNV isolate 220-90) was added to each well, and plates were incubated for $30 \mathrm{~min}$ on a rocker platform at $18^{\circ} \mathrm{C}$. Complement (1:10 dilution) was added to each well and plates incubated an additional $30 \mathrm{~min}$ at $18^{\circ} \mathrm{C}$. Complement was obtained from SPF trout (Clear Springs stock) that remained off feed for at least 2 wk. Samples were inoculated in duplicate onto polyethylene glycol (PEG) pretreated monolayers of Epithelioma papulosum cyprini (EPC) cells (Fijan et al. 1983) grown in 48-well plates and plates were incubated for $1 \mathrm{~h}$ on a rocker platform at $18^{\circ} \mathrm{C}$ to allow for viral adsorption. The inoculum was removed, monolayers overlaid with methyl-cellulose based media (Sigma Chemical, St. Louis, MO, USA), and plates were incubated at $18^{\circ} \mathrm{C}$ for $6 \mathrm{~d}$. Cells were fixed and stained with crystal violet/formalin and neutralization titers were determined by taking the reciprocal of the dilution resulting in a $50 \%$ reduction in plaques compared to negative controls. Positive and negative serum samples were used as controls in all tests.

Virus assay. Skin and GI mucus, along with kidneyLiver-spleen homogenates from a minimum of $20 \%$ of the daily mortalities from each tank, were assayed for virus. Quantification of virus isolated from mucus samples or mortalities was accomplished using a plaque assay procedure previously described (LaPatra et al. 1989).

Histology. Histological samples were embedded in paraffin blocks by routine methods and $5 \mu \mathrm{m}$ sections were cut and mounted. Sections were stained in hematoxylin/eosin and examined using light microscopy.

Immunohistochemistry. Samples processed for immunohistochemistry were sectioned as described and mounted on charged precleaned microscope slides (ProbeOn $^{\text {TM }}$ Plus, Fisher Scientific, Pittsburgh, PA, USA) used with a MicroProbe ${ }^{T M}$ manual stainer. An alkaline phosphatase immunohistochemical procedure modified from Drolet et al. $(1993,1994)$ was utilized for visualization of viral antigen using light microscopy. Sections were deparaffinized in Propar (Anatech, Battle Creek, MI, USA) and rehydrated by immersing slides for approximately $10 \mathrm{~s}$ in graded ethanol (95 to $70 \%$ ) to distilled water. To unmask protein antigens crosslinked by prolonged formalin fixation, an antigen retrieval solution (Biogenix, San 
Ramon, CA) was used. Briefly, deparaffinized slides were immersed in the antigen retrieval solution and the solution was brought to a rapid boil in a microwave oven for $3 \mathrm{~min}$. Power was reduced to $50 \%$, and slides were boiled for an additional $7 \mathrm{~min}$. Slides were allowed to cool $20 \mathrm{~min}$ and blocked with $5 \%$ non-fat dried milk in PBS for $1 \mathrm{~h}$. After blotting, monoclonal antibody (3GH136J) to the G glycoprotein of IHNV (Ristow \& Arnzen de Avila 1991) diluted 1:1000 was applied, and slides were incubated for $1 \mathrm{~h}$ at room temperature. Slides were washed 10 times with PBS, and a biotinylated goat anti-mouse IgG (Dako Corporation, Carpinteria, CA) secondary antibody was applied for $30 \mathrm{~min}$ at room temperature. After washing, ABC-APase (Vector Laboratories, Burlingame, CA) was applied for $30 \mathrm{~min}$, then the substrate (Vector Red, Vector Laboratories, Burlingame, CA) was applied, and color development was allowed to proceed for 10 to $15 \mathrm{~min}$ at room temperature. The reaction was stopped by rinsing for $5 \mathrm{~min}$ in distilled water. Tissues were then counterstained in hematoxylin for 2 min followed by a tap water rinse for 5 min. Slides were dehydrated by immersing for approximately $10 \mathrm{~s}$ in distilled water, 70,85 and $95 \%$ ethanol and coverslipped using Permount mounting media (Fisher Scientific).

Prior to immunostaining of samples, extensive preliminary testing to achieve optimal identification of viral antigen was conducted. This involved utilizing tissues known to be infected with IHNV and negative tissues. A number of primary monoclonal antibodies to IHNV (Ristow \& Arnzen de Avila 1991) were tested for their ability to detect antigen with minimal background staining. Once appropriate dilutions of primary and secondary antibody were determined, control sections were processed to detect non-specific reagent binding. Controls included tissues known to contain IHNV, tissues free of IHNV, blocking solution substituted for the primary antibody, blocker substituted for both primary and secondary antibodies, and negative Ig isotype control substituted for primary antibody. By this procedure, any antibody or reagent producing background reaction was identified. Known negative tissues (from mock challenged fish) were always run with tissues obtained from IHNV challenged fish.

Statistical analysis. Virus and neutralization titers were analyzed using a 1-way analysis of variance (ANOVA). Differences in cumulative mortality between infected and uninfected treatment groups were determined by chi-square analysis. Since some values were missing due to mortalities in infected groups of fish, data were analyzed using split-plot analysis. Values were considered significantly different at $p$ values $<0.05$.

\section{RESULTS}

\section{Cumulative mortality and viral isolation}

In Expt 1, fish infected with IHNV by injection exhibited a cumulative mortality of $87 \%(52 / 60)$ with daily mortality reaching a maximum at 6 dpe (Table 2). Mortality in the waterborne exposed group reached a maximum at 5 dpe with a cumulative mortality of $27 \%$ $(16 / 60)$. There was a significant difference $(p<0.05)$ in cumulative mortality between fish infected by the 2 methods. In Expt 2, waterborne challenged fish had a cumulative mortality of $59 \%(47 / 80)$, and daily mortality reached a maximum at 8 dpe (Table 2). Mortality was not observed in mock exposed fish in either experiment.

In Expt 1, mucus collected from the skin and GI tract of fish challenged with IHNV by injection or waterborne exposure contained virus at concentrations ranging from $1.7 \times 10^{1}$ to $2.0 \times 10^{7} \mathrm{pfu} \mathrm{ml}^{-1}$. Virus titers in skin and GI tract mucus were significantly higher $(p<0.05)$ for fish exposed to IHNV by the injection route compared to waterborne exposure (Fig. 1). The number of fish testing positive for virus in skin and GI mucus reached a maximum at 3 dpe in both treatment groups (data not shown).

In Expt 2, virus was only isolated from the GI tract of infected fish at 7 dpe, while samples of external mucus tested positive at 1,7 and 14 dpe; however, only 1 of 5 fish had a positive titer at Day 14 (data not shown). No virus was detected in either skin or GI mucus beyond 14 dpe, and virus was not isolated from mock challenged fish in either experiment.

\section{Antiviral activity in cutaneous and gastrointestinal mucus}

In Expt 1, antiviral activity was detected in the skin mucus from a small number $(8 / 82)$ of fish but at rela-

Table 2. Oncorhynchus mykiss. Cumulative percent mortality of juvenile rainbow trout challenged with infectious hematopoietic necrosis virus (IHNV). Fish in Expt 1 were either waterborne exposed to $10^{4} \mathrm{pfu} \mathrm{m}^{-1}$ IHNV, injected with $10^{4} \mathrm{pfu} \mathrm{fish}^{-1}$ or mock exposed and monitored for $10 \mathrm{~d}$, while fish in Expt 2 were waterborne exposed to $10^{4} \mathrm{pfu} \mathrm{ml}^{-1}$ IHNV

or mock exposed and monitored for $28 \mathrm{dpe}$. nd: not done

\begin{tabular}{|c|c|c|}
\hline \multirow[t]{2}{*}{ Treatment } & \multicolumn{2}{|c|}{ Cumulative mortality (\%) } \\
\hline & Expt 1 & Expt 2 \\
\hline Mock challenge & $0 \quad(0 / 29)$ & $0 \quad(0 / 41)$ \\
\hline Waterborne challenge & $27(16 / 60)$ & $59(47 / 80)$ \\
\hline Injection challenge & $87 \quad(52 / 60)$ & nd \\
\hline
\end{tabular}




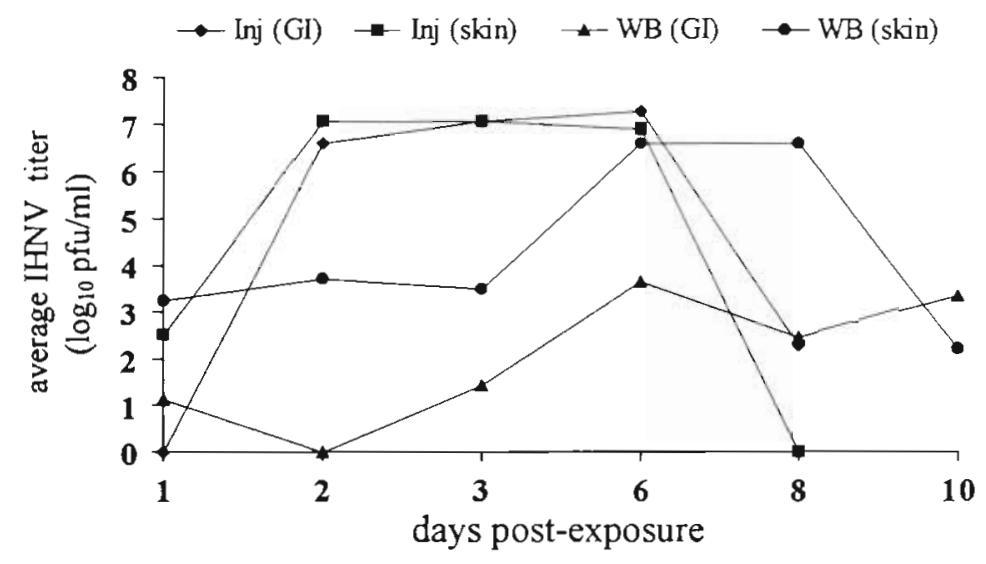

Fig. 1. Oncorhynchus mykiss. Average IHNV titer (expressed as $\log _{10}$ pfu $\mathrm{ml}^{-1}$ ) in skin and lower GI tract mucus of fish challenged with IHNV by injection or waterborne exposure in Expt 1. At each sample pount, titers were averaged from samples of 5 fish. Due to higher mortalities in the injection challenged group, average titer for Day 8 was derived from a sample of 2 fish No fish remained in the injection challenged group by Day 10. Injection challenged fish had significantly higher virus titers $(p<0.05)$ in both skin and GI mucus than waterborne exposed fish. Inj: injection challenge; WB: waterborne challenge

\section{Pathology and immunohistochemistry}

Histological examination of dorsal skin and muscle sections of fish in the first experiment identified subtle pathological changes associated with IHNV infection. A moderate inflammatory response (infiltration of lymphocytes) was observed in the epidermal region of the skin at 3 dpe and was detected out to 10 dpe. Small, rare areas of epithelial cell necrosis within the skin was observed in small numbers of fish.

In Expt 2, histological evaluation of IHNV infected fish revealed minor areas of cellular necrosis in the basal epithelial layer of the skin (Fig. 2A), but only faint staining of viral antigen was observed by immunohistochemistry. Areas of cellular destruction were observed in the gill tissue of severely infected fish (Fig. 2B). In all instances where tissue damage to skin and gills was observed, internal organs showed pathological tively low titers ( 8 to 16 ) (data not shown). In mucus samples collected from the GI tracts of the same fish, however, average titer values showed significant differences $(p<0.05)$ between the different treatment methods (Table 3). Gastrointestinal mucus from mock exposed fish showed the highest average titer at 11.4, while GI mucus from waterborne exposed fish had an average titer of 6.4 . Fish which were injected with virus had the lowest the average titer (1.27).

In Expt 2, IHNV neutralizing activity was not detected in cutaneous mucus collected from mock exposed fish, and detected in infected fish only at 1 dpe (data not shown). Comparison of antiviral activity in the GI mucus of infected and uninfected fish showed no significance difference when averaged over the entire $28 \mathrm{~d}_{i}$ however, a time-wise comparison revealed statistical significance $(p<0.05)$ only at 7 dpe, when virus involvement was most severe (Table 4).

\section{Anti-IHNV antibody production in cutaneous mucus, GI mucus and serum}

No anti-IHNV antibodies were detected by ELISA in the cutaneous and GI mucus of infected or uninfected fish tested out to 28 dpe. Fish surviving IHNV challenge, however, showed anti-IHNV neutralizing antibodies in pooled serum samples at 21 and 28 dpe (Table 5). Antibodies were not detected in unchallenged fish.
Table 3. Oncorhynchus mykiss. Anti-IHNV neutralizing activity in GI mucus samples collected from samples ( 5 fish per sample) in infected and uninfected treatment groups out to 10 dpe. Titers were determined by complement dependent neutralization and are given as the reciprocal of the highest dilution which resulted in a $50 \%$ reduction in viral plaques. Titers recorded as less than the lowest dilution tested (e.g. <4) were treated as zero for analysis, while titers recorded as greater than or equal to the highest dilution tested (e.g. $\geq 32$ ) were treated as the given value. Blanks $(-)$ represent missing samples due to high mortalities in the injection challenged group. nd: not done

\begin{tabular}{|c|c|c|c|c|c|c|c|}
\hline \multirow{2}{*}{$\begin{array}{c}\text { Sample } \\
\text { no. }\end{array}$} & \multicolumn{7}{|c|}{ Days post-exposure } \\
\hline & 0 & 1 & 2 & 3 & 6 & 8 & 10 \\
\hline \multicolumn{8}{|c|}{ Mock challenge } \\
\hline 1 & 8 & $\geq 32$ & nd & 4 & nd & $\geq 32$ & nd \\
\hline 2 & 8 & 4 & nd & 8 & nd & 16 & nd \\
\hline 3 & $<4$ & $<4$ & nd & 4 & nd & 8 & nd \\
\hline 4 & 8 & $\geq 32$ & nd & 4 & nd & $<4$ & nd \\
\hline 5 & $\geq 32$ & 8 & nd & 16 & nd & 4 & nd \\
\hline \multicolumn{8}{|c|}{ Waterborne challenge } \\
\hline 1 & nd & 16 & 4 & 4 & 4 & 8 & $<4$ \\
\hline 2 & nd & $\geq 32$ & 4 & $<4$ & 8 & $<4$ & 8 \\
\hline 3 & nd & 8 & 8 & 8 & 8 & $<4$ & $<4$ \\
\hline 4 & nd & 8 & 16 & $<4$ & 4 & $\geq 32$ & $<4$ \\
\hline 5 & nd & 4 & 4 & $<4$ & $<4$ & $<4$ & 4 \\
\hline \multicolumn{8}{|c|}{ Injection challenge } \\
\hline 1 & nd & 4 & $<4$ & $<4$ & $<4$ & $<4$ & - \\
\hline 2 & nd & 8 & $<4$ & $<4$ & $<4$ & $<4$ & - \\
\hline 3 & nd & 4 & $<4$ & $<4$ & $<4$ & - & - \\
\hline 4 & nd & $<4$ & 4 & $<4$ & $<4$ & - & - \\
\hline 5 & nd & 8 & $<4$ & $<4$ & $<4$ & - & - \\
\hline
\end{tabular}


Table 4. Oncorhynchus mykiss. Anti-IHNV neutralizıng activity in GI mucus collected from samples ( 5 fish per sample) from infected and uninfected treatment groups in Expt 2. A complement-dependent neutralization assay was used, and titers are given as the reciprocal of the highest dilution which resulted in a $50 \%$ reduction in viral plaques. Titers recorded as less than the lowest dilution tested $($ e.g. $<4)$ were treated as zero for analysis, while titers recorded as greater than or equal to the highest dilution tested (e.g. 232 ) were treated as the given value. A significant treatment difference $(p<0.05)$ was present at 7 d post-exposure. Blanks (-) represent missing samples (due to mortalities)

\begin{tabular}{|c|c|c|c|c|c|}
\hline \multirow{2}{*}{$\begin{array}{c}\text { Sample } \\
\text { no. }\end{array}$} & \multicolumn{5}{|c|}{ Days post-exposure } \\
\hline & 1 & 7 & 14 & 21 & 28 \\
\hline \multicolumn{6}{|c|}{ Mock challenge } \\
\hline 1 & $\geq 32$ & $\geq 32$ & 4 & $<4$ & 8 \\
\hline 2 & $\geq 32$ & $\geq 32$ & 16 & $<4$ & 4 \\
\hline 3 & $\geq 32$ & 4 & $<4$ & $<4$ & $\geq 32$ \\
\hline 4 & 8 & 16 & 8 & $<4$ & 4 \\
\hline 5 & 16 & 16 & $<4$ & $<4$ & 16 \\
\hline \multicolumn{6}{|c|}{ Waterborne challenge } \\
\hline 1 & 16 & 4 & $\geq 32$ & $<4$ & - \\
\hline 2 & 8 & $<4$ & 4 & $<4$ & - \\
\hline 3 & 16 & $<4$ & $<4$ & $<4$ & - \\
\hline 4 & $\geq 32$ & $<4$ & $<4$ & $<4$ & - \\
\hline 5 & $\geq 32$ & $<4$ & $\geq 32$ & $<4$ & - \\
\hline
\end{tabular}

Table 5. Oncorhynchus mykiss. Anti-IHNV neutralizing antibodies in the serum of rainbow trout challenged with IFINV. A. complement-dependent neutralization assay was used, and titers are given as the reciprocal of the highest dilution which resulted in a $50 \%$ reduction in viral plaques. Serum was pooled from samples of 5 fish. Fish were either waterborne exposed to $10^{4} \mathrm{pfu} \mathrm{m}^{-1}$ IINV or mock exposed to PBS

\begin{tabular}{|lcccrr|}
\hline Treatment & \multicolumn{5}{c|}{ Days post-exposure } \\
& 1 & 7 & 14 & 21 & 28 \\
\hline Mock challenge & 0 & 0 & 0 & 0 & 0 \\
Waterborne challenge & 0 & 0 & 0 & 80 & 40 \\
\hline
\end{tabular}

\section{DISCUSSION}

In this study, IHNV was isolated from the skin and GI mucus of rainbow trout following virus challenge. The number of fish testing positive for virus in the skin and GI mucus in Expt 1 was found to increase and reach a maximum at 3 dpe. LaPatra et al. (1989) demonstrated similar patterns of virus infection in external mucus, and it has been shown that virus replication in excised epidermal tissues slows between 3 and 4 dpe (Yamamoto et al. 1992). In Expt 2, virus was not isolated signs associated with severe infection. Cell necrosis was extensive in the anterior kidney, spleen, peripancreatic tissue, liver, heart and gastric smooth muscle, and viral antigen was visualized by immunohistochemical staining (Fig. 3). In the kidney and spleen, there was extensive necrosis and fragmentation of hematopoietic cells. In severely infected fish, focal areas of necrosis were observed in the liver and gastric smooth muscle; and myocytes within the stomach wall were fragmented, hyalinized, swollen and had muclear pyknosis. Viral antigen localized to endothelial cells of blood vessels and adjacent interstitium in the stomach and pancreatic tissue. Viral antigen and associated necrosis of pancreatic acinar cells was observed, but less frequently than antigen localization to interstitial vasculature.

Fig. 2. Oncorhynchus mykiss. (A) Skin section of IHNV infected rainbow trout at 7 dpe showing cellular necrosis (arrows) in the basal layer of the epithelium adjacent to dermal tissue; (B) cell destruction (arrows) in gill tissue of IHNV infected rainbow trout at 7 dpe

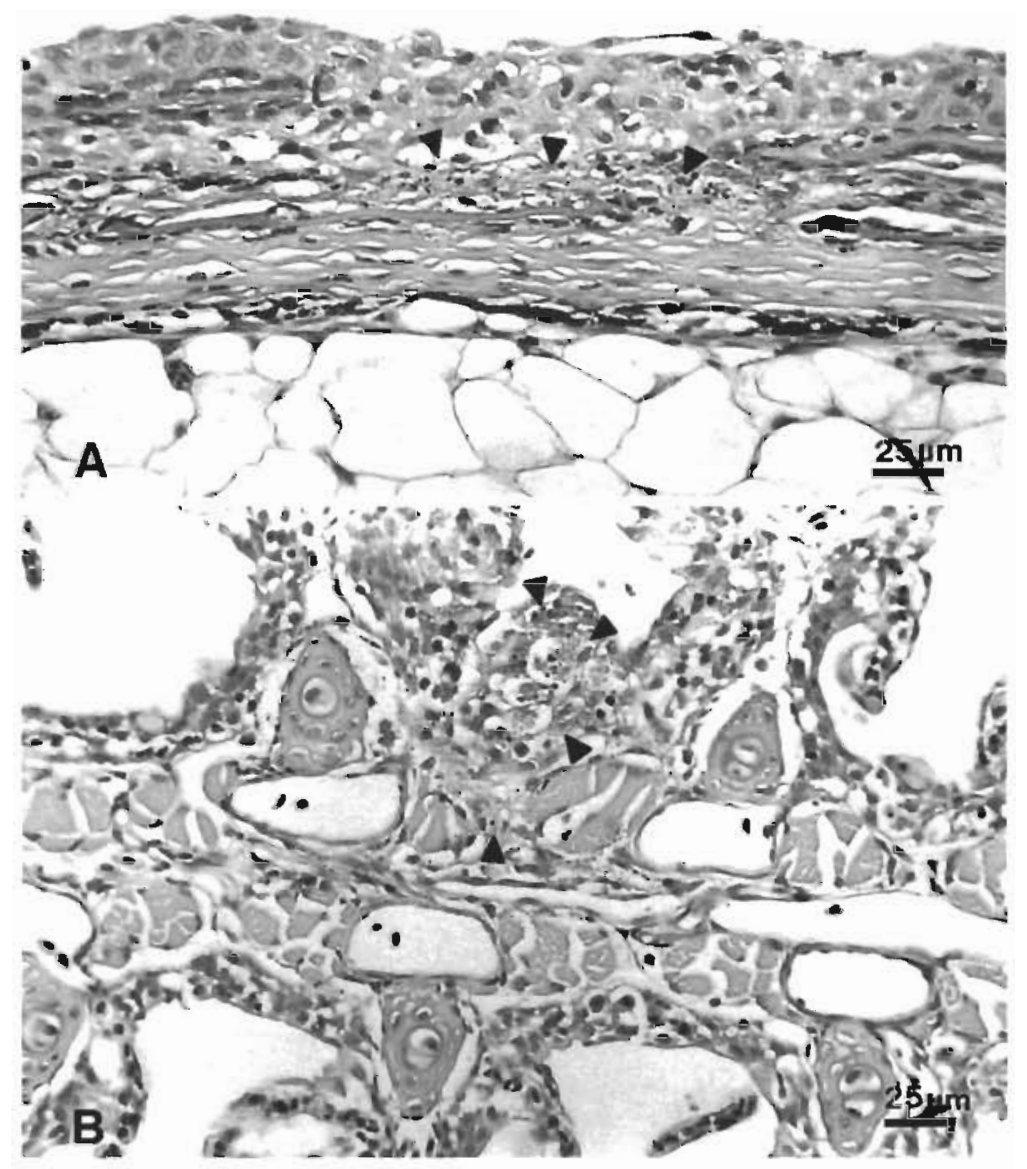



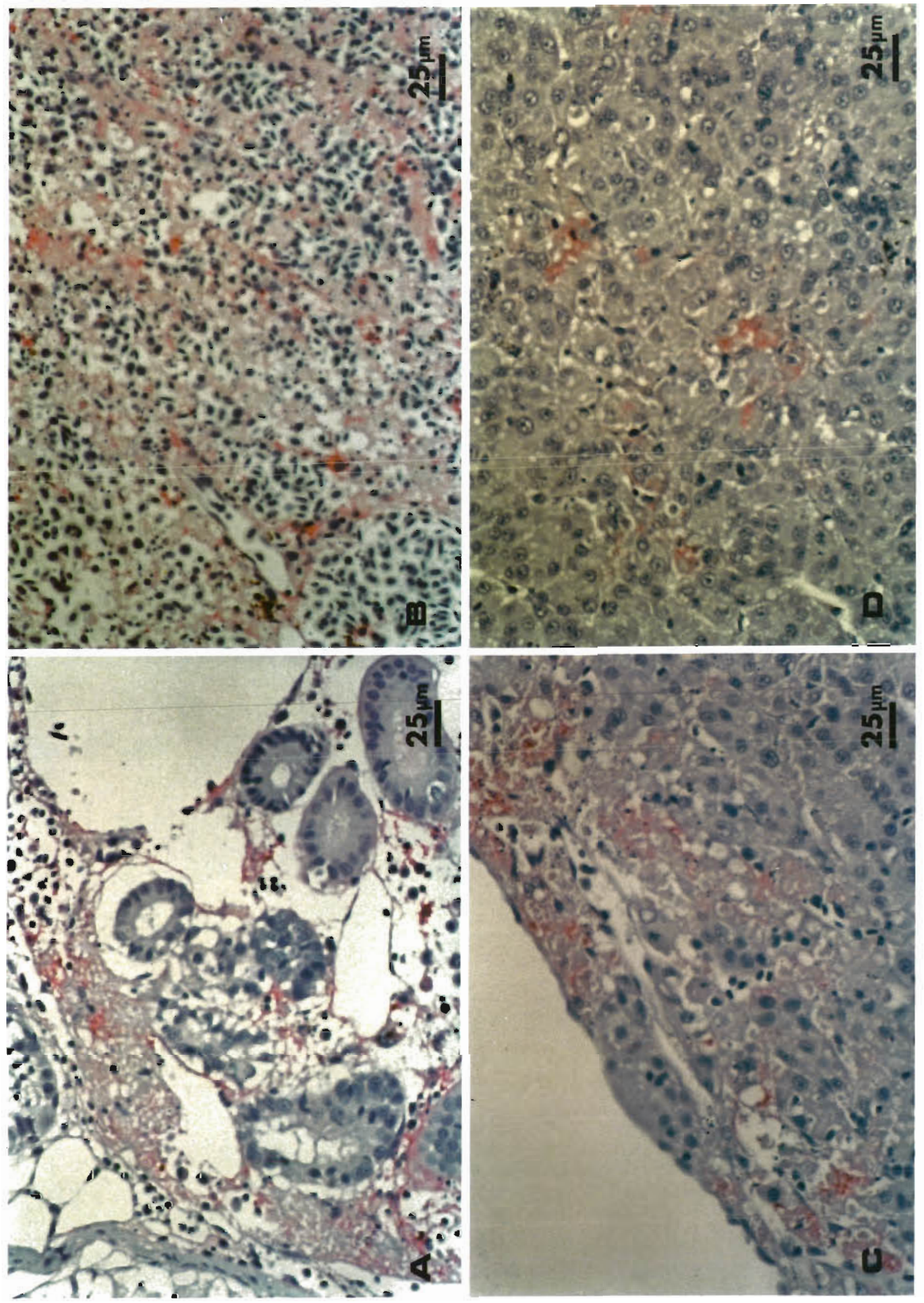

它 

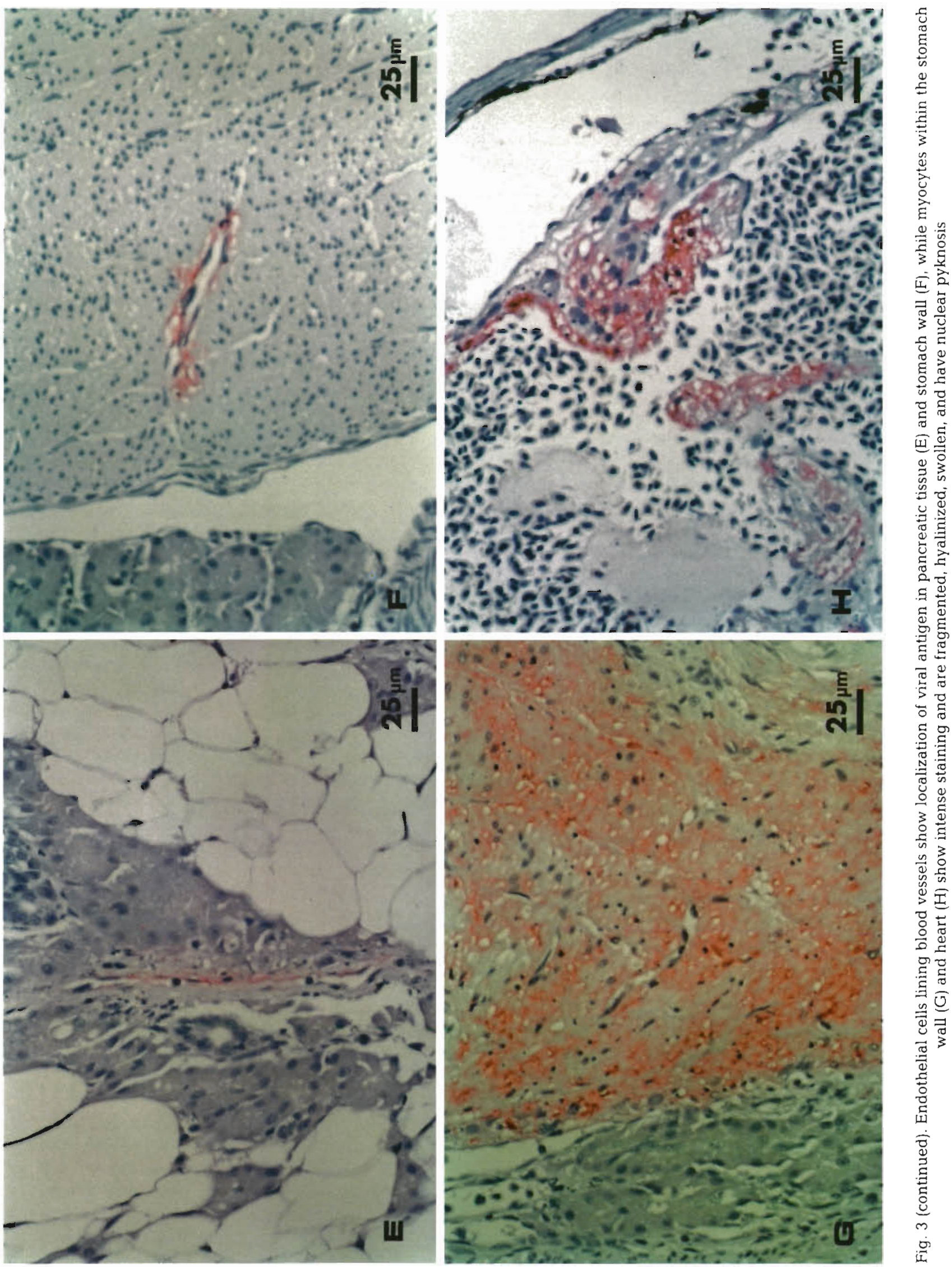
beyond 14 dpe from either the skin or GI mucus. This suggests that the virus may have been cleared from these areas and viral replication was not occurring at these later times. Yamamoto et al. $(1990,1992)$ used immunohistochemistry and plaque assay to observe and quantify virus antigen in the skin of waterborne exposed fish and in excised epidermal tissues of rainbow trout. They suggested that the skin may be a portal of entry and viral replication may aid in horizontal transmission. This study confirms early presence of virus in the skin mucus, but histological observations showed little associated pathology unless fish were undergoing severe systemic infection. Immunohistochemical staining revealed only minor virus involvement in areas of cellular necrosis within the basal lamina of the skin. These regions did not appear to be major sites of virus replication. Intense staining and associated pathological changes were consistently observed in the internal organs of infected fish. Viral antigen was not observed at the skin surface. Differences from previous reports may be due in part to differences in location of sample excision (dorsal-lateral rather than ventral-abdominal), challenge dose, or sensitivity of staining using antigen retrieval procedures. Recent studies have identified the esophagus/cardiac stomach region as a site of early viral pathogenesis, and it appears this may play a greater role as a possible portal of entry for the virus than infection and entry through the skin (Helmick 1995a, b).

What is obvious from this study is that if virus replication within the epithelial cells at the surface of the skin is occurring, minimal pathology is associated. It may be possible that an increase in virus concentration on the skin is due to adherence rather than large scale replication within the epithelial cells. If surface epithelial cells are producing virus, then mechanisms must exist which eliminate infection prior to cell destruction in fish surviving an epizootic. In severely infected fish, destruction of epithelial cells adjacent to dermal blood vessels was observed, and it is possible that this could serve to transport virus to the surface of the fish and therefore act as a means of horizontal transmission prior to death of the animal.

Fish surviving an IHN epizootic are known to elicit a systemic immune response confirmed by the presence of neutralizing antibody titers in the serum (LaPatra et al. 1993, Ristow et al. 1993), but not all surviving fish have detectable levels of antibody to IHNV (Ristow et al. 1993). Mortality from IHN reaches a maximum approximately $1 \mathrm{wk}$ after virus exposure, but antiIHNV antibodies are generally not detected until some time later. These observations suggest that other mechanisms, which act early in the infection, exist and are important in resistance to IHNV. In this study, mucosal sites as well as serum samples were evalu- ated. Antibody production was observed at 21 and 28 dpe in pooled serum samples from juvenile rainbow trout (mean weight $2.4 \mathrm{~g}$ ) confirming their ability to mount a humoral immune response to IHNV. Antibody production in the mucus (skin and GI tract) in response to stimulation with virulent virus was not observed. However, antiviral activity was observed in the mucus. It is possible that this activity could serve as an early defense mechanism against IHNV and may be due to an innate potentially non-lymphoid substance. Yamamoto et al. (1992) saw no differences in the ability to infect excised epithelial tissues from fish surviving a previous exposure to IHNV compared to fish never infected with the virus, and suggested that long term established immunity in the skin may be minimal in response to IHNV. The present study supports this, and suggests that mucosal antibodies are not involved in preventing infection or clearing virus from these sites. However, it should be noted that Ig isotypes or Ig molecules incapable of binding to the anti-trout antibody used in the ELISA would not be detected.

Antiviral activity, measured by the ability to neutralize IHNV, was detected in the mucus of rainbow trout. Neutralizing titers were greatest in the GI tract of uninfected fish and therefore were non-antibody mediated. In fish challenged by injection, this activity was detected in the GI mucus at 1 dpe but was minimal thereafter, suggesting an inhibition of antiviral activity due to increased virus replication had occurred. Fish undergoing a more natural infection (waterborne exposure) had detectable antiviral titers for a much longer period of time, but at significantly lower levels than uninfected fish. Severe infection (injection challenge) rapidly eliminated the amount of antiviral activity that was detected. Expt 2 confirmed the presence of IHNV neutralizing activity in these secretions, and again, intestinal mucus had a greater level of antiviral activity than cutaneous mucus. The low levels of antiviral activity detected in the skin mucus may be related to the dilute nature of the samples obtained from these juvenile fish, but the mere fact of its detection suggests that the external mucus may serve as more than just a physical barrier.

Non-lymphoid antibacterial compounds have been identified in fish mucus and may be associated with the presence of certain protein or carbohydrate moieties (Ingram 1980). Austin \& McIntosh (1988) found that bacterial growth was inhibited in the presence of skin and eye secretions from rainbow trout. Other researchers have found that mucus from uninfected rainbow trout exhibited anti-Vibrio anguillarum activity and suggested that external and gut mucus may represent a first line of defense due to the presence of antimicrobial activity (Harrell et al. 1976). Lysozyme (Fletcher \& Grant 1968, Fletcher \& White 1973) and 
natural agglutinins and lysins (Spitzer et al. 1976) are also present in the skin mucus of fish. Furthermore, the ability of fish to alter the amount of mucus secreted in response to stressors is thought to influence the level of initial resistance to invasion by microorganisms (Pickering 1976, Pickering \& Macey 1977)

Early on, it was suggested that development of effective viral vaccines for fish would only be accomplished when a greater understanding of the immune system of fish was achieved (Amend \& Smith 1975). Since then, much has been learned about the immune response to IHNV, but as yet no efficacious marketable vaccines exist. The need for further characterization of the total immune response to IHNV is therefore apparent. This study has focused on mucosal sites in rainbow trout which act as barriers which must be penetrated for internal viral infection to occur. In an evaluation of the immunity at these sites in response to IHNV, it was discovered that innate anti-viral factors exist in GI mucus and to a lesser extent in cutaneous mucus of skin. Detection of antiviral activity was significantly higher in uninfected fish (not exposed to virus) and was not stimulated by exposure to IHNV. This paper is the first report that rainbow trout possess an innate, possibly non-lymphoid, mechanism of protection that may be important as a first line of defense against IHNV.

Acknowledgements. The authors extend their appreciation to Dr Randy MacMillan for the opportunity to perform experiments at the research facility at Clear Springs Foods. Pam Dilbeck at the Washington Animal Disease Diagnostic Laboratory provided invaluable assistance with immunohistochemical procedures. We thank Sunshine Walker, Brenda Vincent, Leslie Grabowski and Jeanene de Avila for their technical assistance, and Dr Marc Evans from the Washington State Program in Statistics for his help in statistical analysis of data. This is scientific paper 8126 from the College of Agriculture and Home Economics Research Center of Washington State University. This work was supported in part by agreement 95-38500-1458 to the Western Regional Aquaculture Consortium from the USDA Cooperative State Research Education and Extension Service and USDA-NRI grant 9337204-9297.

\section{LITERATURE CITED}

Amend DF (1970) Control of infectious hematopoietic necrosis virus disease by elevating the water temperature. J Fish Res Bd Can 27:265-270

Amend DF, Smith L (1975) Pathophysiology of infectious hematopoietic necrosis virus disease in rainbow trout: hematological and blood chemical changes in moribund fish. Infect Immun 11:171-179

Arkoosh MR, Kaattari SL (1990) Quantitation of fish antibody to a specific antigen by an enzyme linked immunosorbent assay (ELISA). In: Stolen JS, Fletcher TC, Anderson DP, Roberson BS, van Muiswinkel WB (eds) Techniques in fish immunology. SOS Publications, Fairhaven, NJ, p 15-24
Austin B, McIntosh D (1988) Natural antibacterial compounds on the surface of rainbow trout. J Fish Dis 11:275-277

Davidson GA (1991) Aspects of mucosal 1mmunity in rainbow trout, Oncorhynchus mykiss (Walbaum 1792). PhD thesis, Aberdeen University

DeLuca D, Wilson M. Warr GW (1983) Lymphocyte heterogeneity in the trout, Salmo gairdneri, defined with monoclonal antibodies to IgM. Eur J Immunol 13:546-551

Drolet BS, Rohovec JS, Leong JC (1993) Serological identification of infectious hematopoietic necrosis virus in fixed tissue culture cells by alkaline phosphatase immunocytochemistry. J Aquat Anim Health 5:265-269

Drolet BS, Rohovec JS, Leong JC (1994) The route of entry and progression of infectious hematopoietic necrosis virus in Oncorhynchus mykiss: a sequential immunohistochemical study. J Fish Dis 17:337-347

Fijan N, Sulimanovic D, Bearzotti M, Muzinic D, Zwillenberg LD, Chilmonczyk S, Vauthaucrot JF, de Kinkelin P (1983) Some properties of the epithelioma papillosum ciprini (EPC) line from common carp Cyprinus carpio. Annls Virol 134:207-220

Fletcher TC, Grant PT (1968) Glycoproteins in the external mucous secretions of the plaice, Pleuronectes platessa, and other fishes. Biochem J 106:12

Fletcher TC, White A (1973) Lysozyme activity in the plaice (Pleuronectes platessa L.). Experientia 29:1283-1285

Gilmore RD, Engelking HM, Manning DS, Leong JC (1988) Expression in E. coli of an epitope on the glycoprotein of infectious hematopoietic necrosis virus protects against viral challenge. Biotechnology 6:295-300

Harrell LW, Etlinger HM, Hodgins HO (1976) Humoral factors important in resistance of salmonid fish to bacterial disease. II. Anti-Vibrio anguillarum activity in mucus and observations on complement. Aquaculture 7:363-370

Hart S, Wrathwell AB, Harris JE, Grayson TH (1988) Gut immunology in fish: a review. Dev Comp Immunol 12 $453-480$

Hasobe M, Saneyoshi M (1985) On the approach to viral chemotherapy against infectious hematopoietic necrosis virus (IHNV) in vitro and in vivo in salmonid fishes. Fish Pathol 20:343-351

Helmick CM, Bailey FJ, LaPatra S, Ristow S (1995a) Histological comparison of infectious hematopoietic necrosis virus challenged juvenile rainbow trout Oncorhynchus mykiss and coho salmon $O$. kisutch gill, esophagus/cardiac stomach region, small intestine and pyloric caeca. Dis Aquat Org 23:175-187

Helmick CM, Bailey FJ, LaPatra S, Ristow S (1995b) The esophagus/cardiac stomach region: site of attachment and internalization of infectious hematopoietic necrosis virus in challenged juvenile rainbow trout Oncorhynchus mykiss and coho salmon O. kisutch. Dis Aquat Org 23:189-199

Ingram GA (1980) Substances involved in the natural resis. tance of fish to infection: a review. J Fish Biol 16:23-60

Jenkins PG, Wrathmell AB, Harris JE, Pulsford AL (1994) Systemic and mucosal immune responses to enterically delivered antigen in Oreochromes mossambicus. Fish Shellfish Immunol 4:255-271

LaPatra SE, Rohovec JS, Fryer JL (1989) Detection of infectious hematopoietic necrosis virus (IHNV) in fish mucus Fish Pathol 24(4):197-202

LaPatra SE, Lauda KA, Morton AW (1991) Antigenic and virulence comparison of eight isolates of infectious hematopoietic necrosis virus from the Hagerman Valley, Idaho, USA. In: Fryer JL (ed) Proceedings of the Second International Symposium on Viruses of Lower Vertebrates Oregon State Univ, Corvallis, p 125-129 
LaPatra SE, Turner T, Lauda KA, Jones GR, Walker S (1993) Characterization of the humoral response of rainbow trout to infectious hematopoietic necrosis. J Aquat Anim Health $5: 165-171$

Leong JC, Fryer JL, Winton JR (1988) Vaccination against infectious hematopoietic necrosis virus. In: Ellis AE (ed) Fish vaccination. Academic Press, New York, p 193-203

Lobb CJ (1987) Secretory immunity induced in catfish, Ictalurus punctatus, following bath immunization. Dev Comp Immunol 11:727-738

Loghothetis PN, Austin B (1994) Immune response of rainbow trout (Oncorhynchus mykiss, Walbaum) to Aeromonas hydrophila. Fish Shellfish Immunol 4:239-254

McGhee JR, Mestecky J, Derzbaugh MT, Eldridge JH, Hirasawa $M$, Kiyono $H$ (1992) The mucosal immune system: from fundamental concepts to vaccine development. Vaccine 10:75-88

Pickering AD (1976) Synthesis of N-acetyl neuraminic acid from $\left({ }^{14} \mathrm{C}\right)$ glucose by the epidermis of the brown trout, Salmo trutta L. Comp Biochem Physiol 54:325-328

Pickering AD, Macey DJ (1977) Structure, histochemistry and the effect of handling stress on the mucous cells of the epidermis of the char Salvelinus alpinus (L.). J Fish Biol 10:505-512

Ristow SS, Arnzen de Avila J (1991) Monoclonal antibodies to the glycoprotein and nucleoprotein of infectious hematopoietic necrosis virus (IHNV) reveal differences among isolates of the virus by fluorescence, neutralization and electrophoresis. Dis Aquat Org 11:105-115

Ristow SS, de Avila J, LaPatra SE, Lauda K (1993) Detection and characterization of rainbow trout antibody against infectious hematopoietic necrosis virus. Dis Aquat Org 15: $109-114$

Rombout JHWM, van den Berg AA (1989) Immunological importance of the second gut segment of carp. I. Uptake and processing of antigens by epithelial cells and macrophages. J Fish Biol 35:13-22

Responsible Subject Editor: J. A. Leong, Corvallis, Oregon, USA
Rombout JHWM, Bot HE, Taverne-Thiele JJ (1989a) Immunological importance of the second gut segment of carp. If Characterization of mucosal leucocytes. J Fish Biol 35:167-178

Rombout JHWM, van den Berg AA, van den Berg CTGS, Witte P, Egberts E (1989b) Immunological importance of the second gut segment of carp. III. Systemic andior mucosal immune responses after immunization with soluble or particulate antigens. J Fish Biol 35:179-186

Service RF (1994) Triggering the first line of defense. Science 265:1522-1524

Spitzer RH, Downing SW, Koch EA, Kaplan MA (1976) Hemagglutinins in the mucus of Pacific hagfish Eptatretus stoutii. Comp Biochem Physiol 54:409-411

St Louis-Cormier EA, Osterland DK, Anderson PD (1984) Evidence for a cutaneous secretory immune system in the rainbow trout (Salmo gairdneri). Dev Comp Immunol 8:71

Vernier JM (1990) Intestinal ultrastructure in relation to lipid and protein absorption in teleost fish. In: Melinger $J$ (ed) Animal nutrition and transport processes. 1. Nutrition in wild and domestic animals. Comp Physiol 5:166-175

Voller A, Bidwell DE, Bartlett A (1979) The enzyme linked immunosorbent assay (ELISA). A guide with abstracts of microplate applications. Dynatech Laboratories, Alexandria, VA

Wolf $K$ (1988) Infectious hematopoietic necrosis. In: Fish viruses and fish viral diseases. Cornell University Press, Ithaca, New York, p 83-114

Yamamoto T, Batts WN, Arakawa CK, Winton JR (1990) Multiplication of infectious hematopoietic necrosis virus in rainbow trout following immersion infection: whole body assay and immunohistochemistry. J Aquat Anim Health 2: $271-280$

Yamamoto T, Batts WN, Winton JR (1992) In vitro infection of salmonid epidermal tissues by infectious hematopoietic necrosis virus and viral hemhorrhagic septicemia virus. J Aquat Anim Health 4:231-238

Manuscript first received: May 18, 1996

Revised version accepted: August 19, 1996 